\title{
Accounting
}

\section{Internal social capital banking and activities of commercial bank}

\author{
Lai Cao Mai Phuong ${ }^{a *}$ and Vu Cam Nhung ${ }^{\mathrm{a}}$
}

\section{${ }^{a}$ Faculty of Finance and Banking, Industrial University of Ho Chi Minh City, Vietnam}

\begin{tabular}{l}
\hline C H R O N I C L E \\
\hline Article history: \\
Received: July 28, 2020 \\
Received in revised format: \\
July 30 2020 \\
Accepted: September 6, 2020 \\
Available online: \\
September 6, 2020 \\
\hline Keywords: \\
Social capital \\
Cooperation \\
Individuals \\
Functional departments \\
Internal \\
Banking \\
\hline
\end{tabular}

\section{A B S T R A C T}

\begin{abstract}
The study aims to explore the impact of internal social capital banking on the operations of commercial banks in Vietnam. The study is executed in two phases. Phase 1 uses the expert method to build scales and design survey questions. In phase two, scale test and structural equation model analysis (SEM) are performed with a sample of 243 questionnaires for directors and deputy directors of branches of 32 commercial banks in Ho Chi Minh City. It also analyzes the contribution of the structure of the relational network within the bank and the quality of the relational network. The research results show that internal banking social capital affects all three operations; namely mobilization, lending and service provision of the banks. Based on the research results, the study proposes an analytical framework to improve the quality of internal banking relationships.
\end{abstract}

(C) 2021 by the authors; licensee Growing Science, Canada

\section{Introduction}

In an organization in general and in the bank in particular, the operations of functional departments play an important role in creating material benefits and intangible resources for the banks. Each functional department has its own mission, but has a close relationship with each other, supporting each other to realize the common goals of the organization. It helps to coordinate well between people in an organization and between functional departments to operate the activities of a unit in the most effective way. It can be said that social relationship is one of the important factors contributing to solving this problem. Wilson (2000) argues that social relationships and trust are the basic basis for human decision-making; most policies and activities in the economy are also governed by these two characteristics. Social relationships also help solve cooperation problems, contributing to increased labor productivity and efficiency in the organization's activities. In countries with good institutions and strong legal systems there are some conditions for the individuals to trust each other. This will benefit the business (Phuong, 2020a), the bank, the financial system (Phuong, 2020b, 2020c) and the country's economy (Pastor \& Ausina, 2008). In the bank, the trust between colleagues, willing to share and support each other will contribute to improving work efficiency and the professional expertise of employees will also increase due to sharing. experience and knowledge (Oh, Chung \& Labianca, 2004). Social relationships that directly affect the operations of the bank in general are expressed through increased trust, sharing, and mutual cooperation among individuals and among functional departments. This is beneficial for banks when they want to exploit the strength of the collective, and want to build their brand image in the marketplace.

\footnotetext{
* Corresponding author.

E-mail address: laicaomaiphuong@iuh.edu.vn (L. C. M. Phuong)
} 
In order to effectively exploit social capital in an enterprise, it is necessary to study both external capital sources and internal capital sources affecting the performance of that enterprise (Hoai \& Dien, 2012). In Vietnam, the number of studies on the impact of social capital on commercial banks' operations is very small. Nhung and Phuong (forthcoming) pointed out that external social capital directly affects the operations of commercial banks. How does internal banking social capital affect the operations of commercial banks? To answer this question, this article will examine the impact of internal social capital on the operations of commercial banks with branches in Ho Chi Minh City.

\section{Literature Review}

According to Marcinkowska (2012), the relationship within the enterprise is the internal relationship between employees and departments. This relationship has an important significance since it not only affects the improvement of the working atmosphere but also increases the spirit of solidarity, teamwork, thereby improving work efficiency. In addition, this relationship also helps employees to support each other to improve their knowledge and ability to adapt to the external environment. Pietruszka-Ortyl (2015) pointed out the internal social capital of the business as the value of the relationship between individuals /employees in the process of implementing organizational goals. Each individual contributes to increased opportunities to create value for the business. Cabrera and Najarian (2015) draw on a social media perspective to explore internal enterprise relationships. Two authors have pointed out, the sales performance of the business is influenced by internal relationships (cooperation between individuals, departments), thereby helping managers to grasp problems about internal enterprise social network, which helps to improve sales efficiency. Oh et al. (2004), by performing a qualitative research on workplace relationships, has shown that when relationships are strengthened with a focus on meaningful purpose. It helps members have better access to resources (Labianca $\&$ Brass, 2006). These relationships will provide effective social capital for the business. The effective management of managers with their teams /departments is a very important factor in improving team performance (Guzzo \& Dickson, 1996). The effectiveness of the team can be assessed through standards such as: quality of work, workload, proactivity, good cooperation with other groups / departments, ability to complete work on time, the ability to quickly respond to requests. The group has a large social capital, the more effective the group is, the better the ability to access resources to maintain and perform the work is.

Some study in a World Bank study measured social capital in Bosnia and Herzegovina. The authors pointed out that the nature of the relationship between individuals is based on the level of trust and mutual cooperation, thereby bringing efficiency to activities and promoting economic development (World Bank, 2002). Yang et al. (2011) studied and analyzed the internal and external relationships of the company affecting the company's sales performance. Research also shows that outside of the external relationship, the network of internal social relationships such as the relationship between employees, departments in the same company will support each other in transferring knowledge and experience. Experience and expertise, thereby helping sales activities more effectively. Thinh (2009) studies on roles, social networks have shown that social networks within enterprises depend on the density of interactions and relationships between individuals and groups. He pointed out the positivity of internal social networks that help exploit individual resources and increase connection and linkage in the group, which helps increase work efficiency. However, the higher the negativity due to group association and trust, the higher the likelihood of excluding people outside the group. This leads to myopia and conservativeness, which can affect jobs, especially jobs that require creativity (Thinh, 2009). Research by Hoai and Dien (2012), surveying 216 real estate enterprises in Vietnam, have shown that internal social capital affects the operations of real estate businesses. Research also shows that besides the positive effect of this network on the business and the economy, it also has the potential to have negative effects. Therefore, it is necessary to have solutions to limit this negative effect.

Some authors (Schenkel \& Garrison, 2009; Nisbet, 2007, Goyal \& Akhilesh, 2007; Chen et al., 2007) have access to social capital within the enterprise, which is the quality of relationships in horizontal system (between employees and between functional departments); and longitudinal relationships (between superior individuals and subordinate individuals, between superior departments and subordinate departments). But these studies have not built an internal social capital scale and have not yet assessed their impacts on corporate performance. Although the scale has not yet been built, previous studies have shown how to access internal social capital enterprises. To overcome the shortcomings of previous studies, Hoai and Dien (2012) integrated two elements of quality and network structure to build an internal social capital scale for businesses in the real estate industry. At the same time, Hoai and Dien (2012) have shown the impact of internal social capital on input activities, production activities and output activities of enterprises. However, this scale is not completely suitable for measuring the banking industry.

Banking is a form of enterprise in the economy. Based on the review of previous theories related to social capital inside enterprises, it is possible to draw the concept that social capital inside banks is the resources of existing individuals, groups and organizations within the network of relationships within the bank based on trust, sharing, support and mutual expectations. 
The theoretical basis has shown that internal social capital of a bank is the network and the quality of relationships within the bank. The structure and quality of the bank's internal relations network are as follows:

Firstly, the structure of the relational network is shown through three aspects: (1) How subjects participate and their position in the network; (2) The horizontal or vertical relationship of the objects in the network; (3) Interactive channels (interactive means) of the entities in the network (Cheng et al., 2006; Goyal \& Akhilesh, 2007; Nisbet, 2007; Schenkel \& Garrison, 2009). This article outlines the actors involved in the horizontal network of relationships within banks, the relationships between employees and between functional departments; and vertically is the relationship between superior individuals and subordinate individuals, between superior functional parts and subordinate functional parts. Second, the quality of the relationship network is expressed through three aspects: (1) trust, expectation, sharing, mutual support and compliance with standards; (2) form of interlocking, reaching outward clusters; (3) the connection, frequency of participation, and support received from participation in the network of social organizations. In addition, when the functional staff and departments work in the spirit of solidarity, willingness to support each other, and share knowledge, which means that internal social capital has shown a positive side for the banking industry, goods, contributing to increasing labor productivity, improving the quality of human resources and transferring knowledge (Ramstrom, 2008). Based on research on previous publications, hypotheses about the impact of internal social capital on banking operations in Vietnam are as follows:

$\mathrm{H}_{1}$ : Increasing the internal social capital of the bank has a positive impact with the increase in the results of capital operations.

$\mathrm{H}_{2}$ : Increasing the internal social capital of the bank has positive effects with the increase in operating results using capital.

$\mathrm{H}_{3}$ : Increasing the internal social capital of the bank has positive effects with the increase in the results of service provision.

Experts have identified that activities in a business in general and commercial banks in particular have a close relationship with each other. Activities in commercial banking are believed to be mutually supportive and have positive effects (Rose \& Hudgins, 2006). The following hypotheses about the impact of bank operations are as follows:
$\mathrm{H}_{4}$ : Increasing the results of operations capital has a positive impact with the increase in the results of activities using capital;
$\mathrm{H}_{5}$ : $\quad$ Increasing the results of using capital has a positive impact with the increase in the results of service provision;

\section{Research method}

The research process is divided into three phases. Stage 1: Using expert interviewing to discover the internal social capital scales of the bank and the operations of commercial banks. Based on the theoretical basis and in-depth discussions with the experts who are leaders of the commercial bank branches to design survey questions and build scales. Stage 2: Scale test for case studies and CFA and model test with SEM analysis. Confidence coefficient (Cronbach's alpha), exploratory factor analysis (EFA) and confirmation factor analysis CFA will be used to test the scale. Confidence coefficients (Cronbach's alpha) and exploratory factor analysis (EFA) help preliminary screen and scale structure identification (Hair, Black, Babin, Anderson \& Tatham, 1998). The CFA affirmative factor analysis method allows testing the theoretical structure of the scales without being biased by measurement error such as the relationship between some research concepts and other concepts (Steenkamp \& Van Trijp, 1991). Therefore, CFA can be used to get the final conclusion about the value of the scale (Conway \& Huffcutt, 2003). To confirm the suitability of a theoretical model, linear structural equation model analysis (SEM) is used. The model is considered to be appropriate for the data when the CFI indicators are 0.9 to $1, \mathrm{CMIN} / \mathrm{df}<2$ (in some cases CMIN / df can be $\leq 3$ (McIver \& Carmines, 1981) and RMSEA < 0.8). The SEM model can calculate measurement errors, in addition it allows to combine implicit concepts with their measurements and can consider measures independently or in combination with theoretical models. for a while (Hulland, Chow \& Lam, 1996). In addition, if the data has a normal distribution, the Maximum Likelihood method will be used to estimate the parameters in the research model.

\section{Results}

In this section, the article will analyze and discuss the results for a sample of 243 branch managers and deputy branch directors of 32 commercial banks in Ho Chi Minh City. According to Bollen (1998) the minimum sample size is 5 samples for one parameter to be estimated. This study has 17 observed variables and 6 potential variables related to each other. This means that there are 23 parameters to be estimated, thus the minimum sample size is 115 observations (5x23). The sample size of the study is $243>115$, and the analysis from the study data is reliable. 
Table 1

Cronbach's alpha and item - total correlation

\begin{tabular}{|c|c|c|c|c|c|}
\hline Model & Variables (code) & Mean & Std. Deviation & Cronbach's alpha & Item - total correlation \\
\hline \multirow{2}{*}{$\begin{array}{l}\text { Independent } \\
\text { variables }\end{array}$} & Cooperation between individuals (CI) & 5.64 & 0.82 & 0.84 & 0.56 \\
\hline & Cooperation between functional departments (CD) & 5.75 & 0.81 & 0.84 & 0.61 \\
\hline \multirow{3}{*}{$\begin{array}{l}\text { Dependent } \\
\text { variable }\end{array}$} & Capital activities (HD) & 5.07 & 1.13 & 0.81 & 0.84 \\
\hline & Using capital activities (CV) & 5.36 & 0.91 & 0.73 & 0.81 \\
\hline & Providing services activities (CU) & 5.54 & 0.98 & 0.73 & 0.79 \\
\hline
\end{tabular}

Source: Authors' calculations from survey data

Cronbach's alpha's confidence coefficients show observed variables on quadratic component scales that measure social capital within banks; all banks' scales have reliability coefficients greater than 0.6 and Item - total correlation are both greater than 0.35 . This result shows that the observed variables are retained for the next factor analysis. The mean value of the variables in Table 1 is 5.07 which is higher than the average of the scale of 3 . These results show that Vietnamese commercial banks have appreciated the network of relationships. relationships between employees and between its own bank divisions.

Table 2

Exploratory factor analysis (EFA)

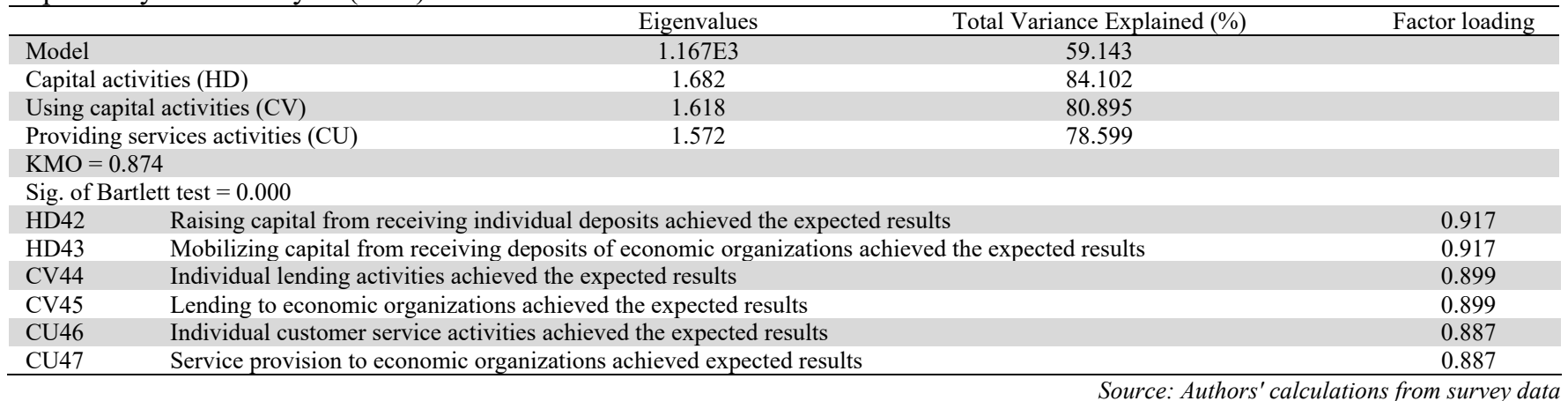

When the two conditions are satisfied, the total Variance Explained must be greater than 50\% and the Factor loading must be 0.5 , then the EFA model is appropriate. The assessment shows that the scale structure does not change, the observed variables included in factor analysis have the value of total variance explained of $59.14 \%$ and factors loading greater than 0.5 , the coefficient KMO is 0.874 (greater than 0.5); Bartlett test significance level is 0.000 . The final analysis results are summarized in Table 2 and Table 3.

Table 3

Rotated Component Matrix

\begin{tabular}{|c|c|c|c|c|}
\hline \multirow{2}{*}{$\begin{array}{l}\text { Independent } \\
\text { variables }\end{array}$} & \multirow[t]{2}{*}{ Survey questions } & \multirow[t]{2}{*}{ code } & \multicolumn{2}{|c|}{ Component } \\
\hline & & & 1 & 2 \\
\hline \multirow{5}{*}{$\begin{array}{l}\text { Cooperation } \\
\text { between } \\
\text { individuals } \\
\text { (CI) }\end{array}$} & The bank creates a good cooperation mechanism between individuals & BT31 & 0.563 & \\
\hline & There is a mechanism to monitor cooperation between individuals & BT32 & 0.670 & \\
\hline & The superiors focus on the cooperation between individuals when assigning the subordinates & BT33 & 0.588 & \\
\hline & Most individuals trust each other & BT34 & 0.806 & \\
\hline & Willingness to share experiences and knowledge in job solving & BT35 & 0.748 & \\
\hline \multirow{6}{*}{$\begin{array}{l}\text { Cooperation } \\
\text { between } \\
\text { functional } \\
\text { departments } \\
\text { (CD) }\end{array}$} & Achieving good results is based on collaboration between individuals & BT36 & 0.817 & \\
\hline & The bank creates a good cooperation mechanism between functional departments & BT37 & & 0.716 \\
\hline & There is a mechanism to monitor cooperation between functional departments & BT38 & & 0.712 \\
\hline & The superiors when assigning the subordinates focus on the cooperation between functional departments & BT39 & & 0.834 \\
\hline & Willing to support each other to accomplish the common goals of the bank & BT40 & & 0.765 \\
\hline & Achieving good results is based on cooperation between functional departments & BT41 & & 0.678 \\
\hline
\end{tabular}

Source: Authors' calculations from survey data

The scale of social capital within banks includes interpersonal cooperation networks (variables BT31, BT32, BT33, BT34, BT35, and BT36) and functional collaboration between departments (BT37, BT38, BT39, BT40, BT41). The structure of the bank's internal social capital scale remained unchanged from its original design.

Testing scales by Confirmatory Factor Analysis (CFA)

Testing the second-order component scale of internal-bank social capital

The bank's internal social capital scale is a multidirectional scale with two components including: (1) the cooperation between individuals in the bank, (2) cooperation between functional departments. 


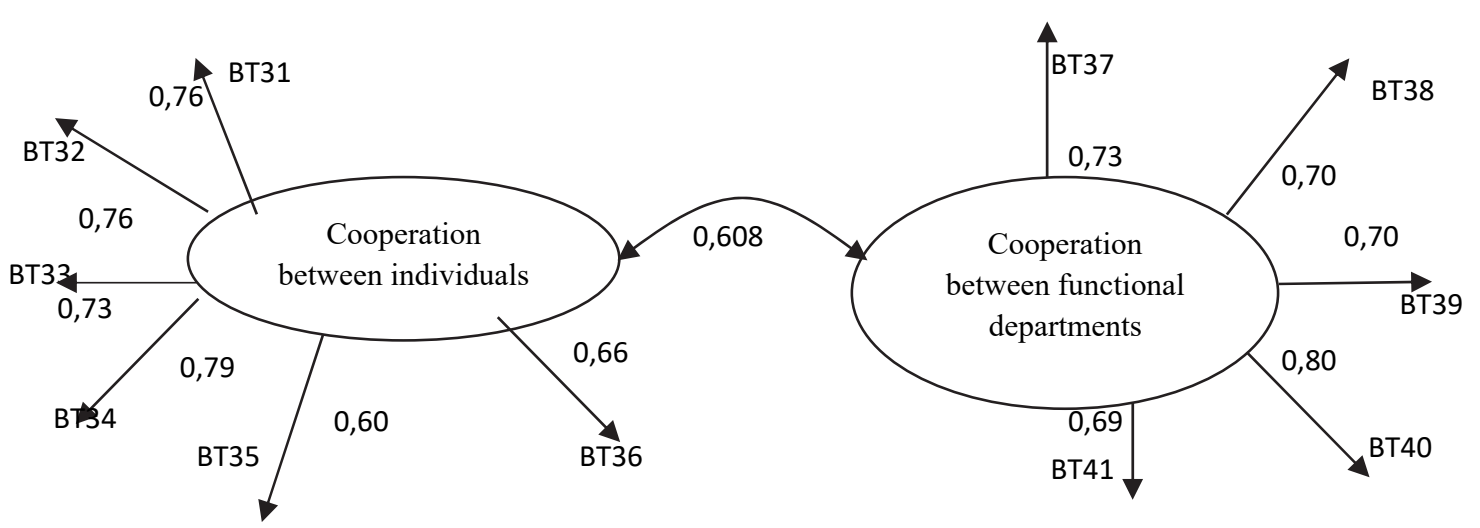

Fig. 1. CFA (standardized) scale of bank' internal social capital

Source: Authors' calculations from survey data

The results of testing the scales of the quadratic component of the bank's internal social capital have affirmed the uniqueness and convergence of all components in the internal social capital scale of banks. With a significance level of $1 \%$, the correlation coefficient between the two components of the concept of internal social capital is less than 1, so these components achieve distinct validity in the same concept.

Table 4

Summary of CFA test results

\begin{tabular}{|c|c|c|c|}
\hline & CFA for the second order component & CFA for theoretical model concepts & Estimated from the SEM model \\
\hline Chi-square & 72.3 & 100.272 & 96.768 \\
\hline Degrees of freedom & 33 & 48 & 48 \\
\hline Probability level & 0.000 & 0.000 & 0.000 \\
\hline CFI & 0.965 & 0.933 & 0.930 \\
\hline RMSEA & 0.070 & 0.079 & 0.069 \\
\hline CMIN/DF & 2.190 & 2.089 & 2.016 \\
\hline Conclusion & distinguished values & distinguished values & distinguished values \\
\hline
\end{tabular}

Source: Authors' calculations from survey data

General Confirmatory Factor Analysis for internal banks - social capital scales and commercial banks' activities.

Table 4 shows the results of the differential value test between concepts in the theoretical model which indicates that these components guarantee discriminant value in the same concept and the uniqueness and convergence of the composition of the social capital scale of banks.

\section{Analysis Structural Equation Modeling (SEM)}

The standardized estimation results of the main parameters in the adjusted model are presented in Table 4 and the standardized estimation results shown in Fig. 3 indicate that the hypothesis is accepted at significance level 1\%. SEM estimation results show that the adjusted theoretical model reaches the level of compatibility with market data (Table 4). The results of the standardized SEM model (Fig. 3) show that the components of the concept of social capital within the bank explain $65.3 \%$ of the variation of capital activity; 70.1\% variation of activities using capital; $69.4 \%$ of the variation in service provision. The exploitation of the bank's internal social capital will help banks strengthen the loyalty of old customers and increase potential customers, promoting better results.

\section{Table 5}

Structure relationship between components in SEM model

\begin{tabular}{|c|c|c|c|c|c|c|}
\hline Hypothesis & & & & Estimate & P-value & Conclusion \\
\hline H1 & HD & $\leftarrow$ & VXHBT & 0.601 & $* * *$ & H1 is accepted \\
\hline $\mathrm{H} 2$ & $\mathrm{CV}$ & $\leftarrow$ & VXHBT & 0.495 & $* * *$ & $\mathrm{H} 2$ is accepted \\
\hline H3 & $\mathrm{CU}$ & $\leftarrow$ & VXHBT & 0.481 & $* * *$ & H3 is accepted \\
\hline $\mathrm{H} 4$ & $\mathrm{CV}$ & $\leftarrow$ & HD & 0.487 & $* * *$ & H4 is accepted \\
\hline H5 & $\mathrm{CU}$ & $\leftarrow$ & $\mathrm{CV}$ & 0.450 & $* * *$ & H5 is accepted \\
\hline
\end{tabular}

Source: Authors calculated from survey data 


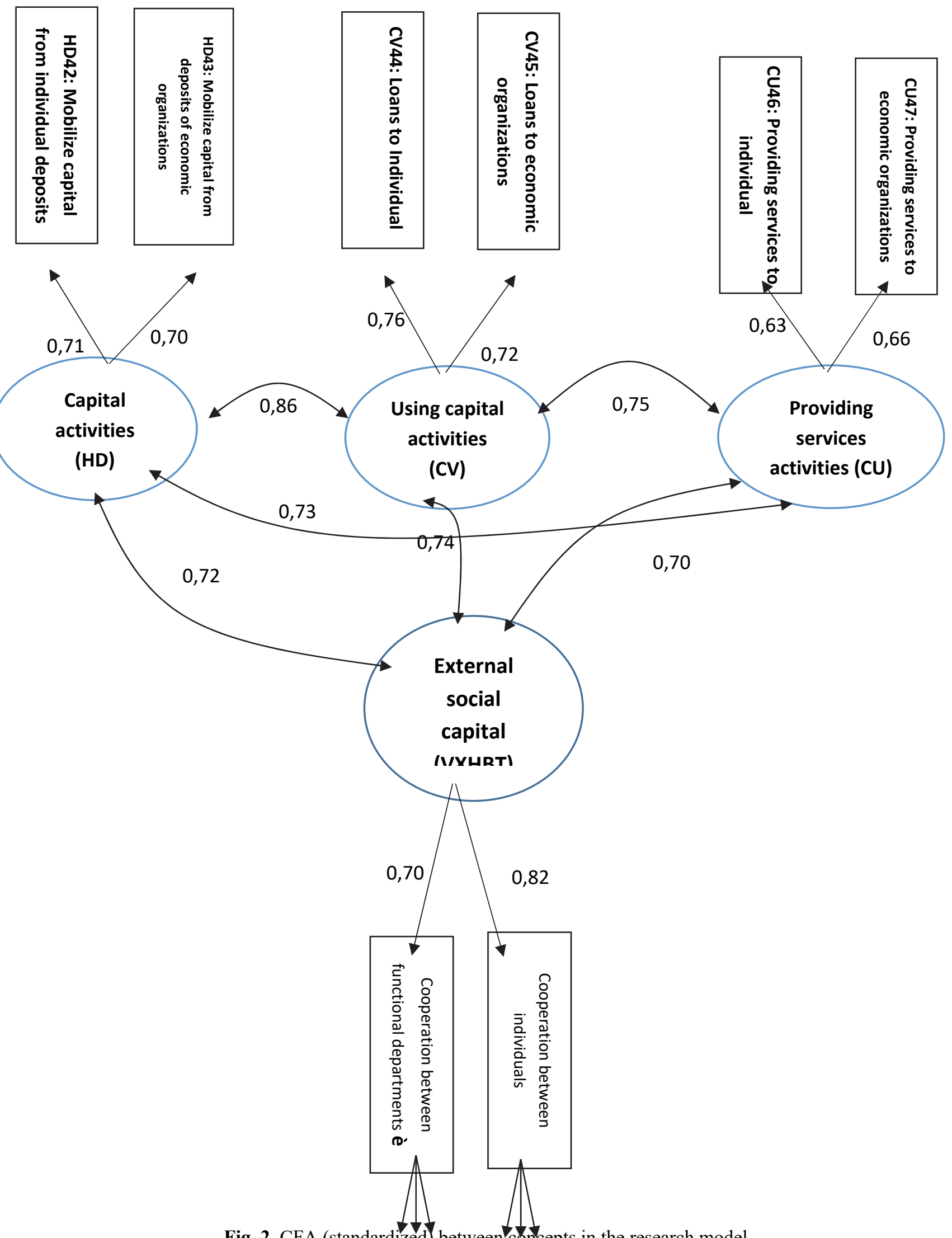

Fig. 2. CFA (standardized) between concepts in the research model 

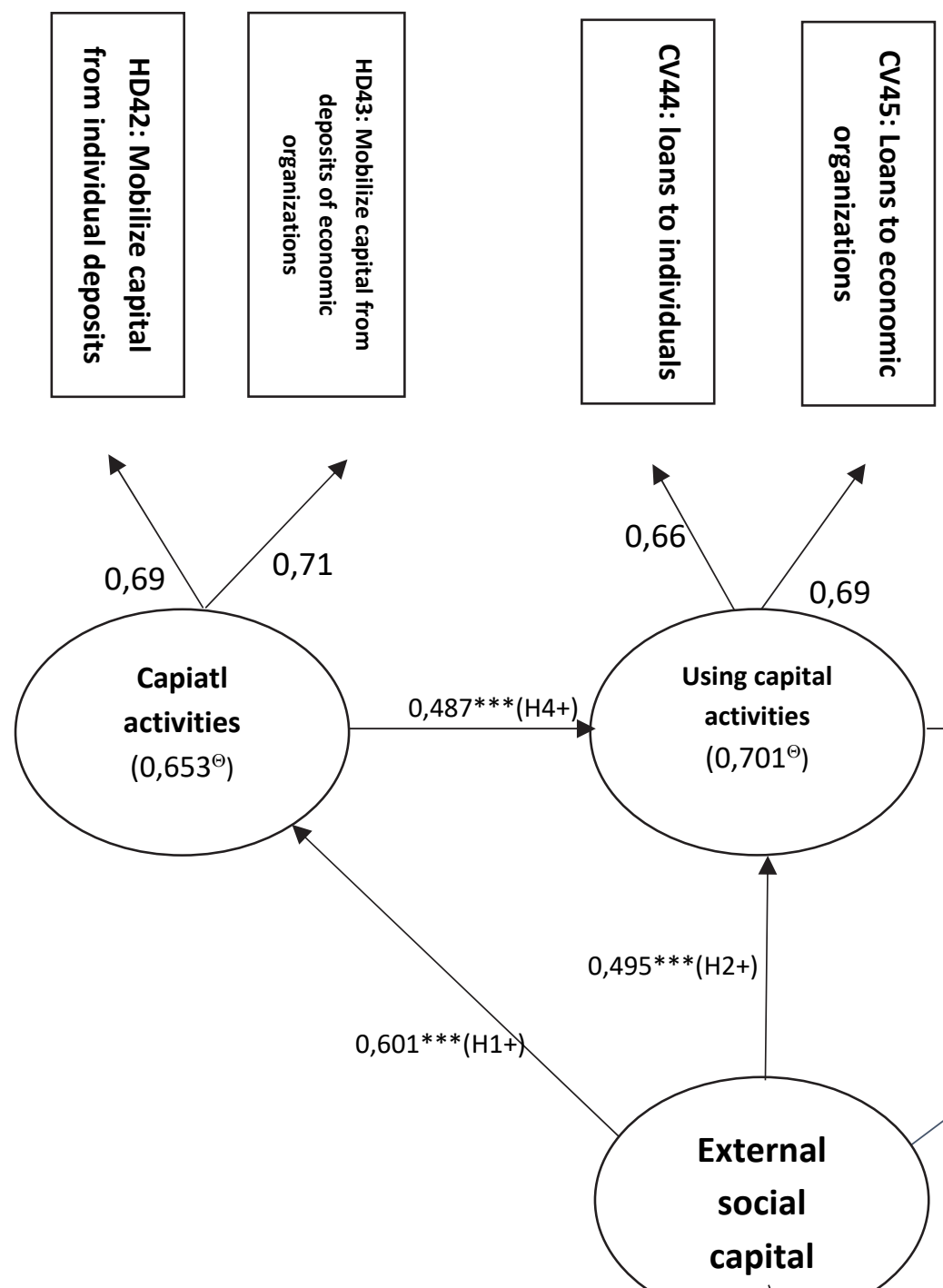


\section{Discuss the research results}

\subsection{Internal bank social capital affects the capital activities of commercial banks}

The hypothesis H1 is accepted with the significance of $1 \%$ in the SEM model, showing that the internal social capital of the bank had a positive and direct impact on the operation of commercial banks. In an organization with a friendly working environment, colleagues are always ready to share knowledge, experience and support each other and the whole team will develop together the professional qualifications of the employees, which in turn, helps solve the job challenges more easily. Especially in the banking industry, providing products and services to customers, requires the professionalism of the staff in solving work. Therefore, with close cooperation between individuals and between departments, it contributes to customer satisfaction. In addition, the good cooperation between functional departments also helps the banking system run well, bring high efficiency to the bank as well as increase customer satisfaction, thereby reinforcing loyalty of the bank, old customers and attract potential customers (including customers referred by former customers). It is possible to realize that the ability to raise capital from customers will increase, helping capital operations achieve better results.

\subsection{Internal social capital affects the use of capital by commercial banks}

With a confidence level of $99 \%$, the hypothesis $\mathrm{H}_{2}$ accepted in the SEM model shows that the internal social capital of the bank has a direct impact on the use of commercial banks' capital. Regression coefficient is 0.495 , indicating that social capital has a positive impact on the use of capital. Through the network of internal relations, close cooperation between individuals and departments helps the bank operate smoothly and better at every step of the process. In addition, with a reasonable management and supervision mechanism of the bank, it will contribute to improving the results of operations (including using capital). With the professionalism of the consulting staff together with the quick work resolution support between departments, it contributes to the smooth and convenient work-solving process, timely meeting the needs of customers, thereby contributing to improve operating results using capital. In addition to the direct impact, the bank's internal social capital also has an indirect impact on the use of capital through capital activities. The bank's internal social capital has direct impact on capital activity with a standardization coefficient of 0.601. Capital activity has a direct impact on the use of capital with the standardization coefficient of 0.487. As a result, the internal social capital of the bank, which indirectly affects the use of capital, is $0.293(=0.601 \times 0.487)$. The total impact of the bank's internal social capital on the use of commercial banks' capital is $0.788(=0.495+0.293)$.

\subsection{Internal bank social capital affects the service provision of commercial banks}

Results from the standardized SEM model show that the bank's internal social capital directly affects the service provision of commercial banks through the acceptance of hypothesis H3 with a normalized regression coefficient of 0.481 , and is accepted at the $1 \%$ level. The network of interpersonal relationships and between departments, plays an important role in the operation of the entire banking system. The better this cooperation is, the more effective a bank's business operations will be. With the professionalism and enthusiasm of a team of direct consultants to customers when needed, along with good coordination between departments, helping the job solving process be smooth, convenient and fast. promptly and promptly respond to the needs of customers. Realizing that the interpersonal support and the cooperation between departments will contribute to improving the quality of customer service. When the quality of service and customer care are improved, the ability to attract customers to use the bank's services will also increase. It will improve the performance of a bank's service delivery.

In addition to the direct effects, the internal social capital of the bank also indirectly affects the use of capital. The bank's internal social capital has a direct impact on capital usage with a standardization coefficient of 0.495 . The use of capital has a direct impact on service provision with the standardization coefficient of 0.450 . Therefore, the internal social capital of the bank that indirectly affects service provision through capital usage is $0.223(=0.495 \times 0.450)$.

\subsection{The relationship between the activities of commercial banks}

This study has demonstrated that the link between the operations of commercial banks is very close and mutually supportive. The hypothesis $\mathrm{H}_{4}$ is accepted with the significance of $1 \%$ proving that capital activities have a direct impact on the use of capital of commercial banks. The regression coefficient is 0.487 , showing that capital activities have positive effects on the use of capital of commercial banks. With a confidence level of $99 \%$, the hypothesis H5 accepted in the SEM model shows that using capital has a direct impact on service provision. The regression coefficient is 0.450 , showing that the use of capital has a direct impact on the service provision of commercial banks. The bank's internal social capital has a direct impact on capital operations with a standardized coefficient of 0.601. Capital activity has a direct impact on capital usage with a standardized regression coefficient of 0.487 . At the same time, the use of capital has a direct impact on service provision with the standardization coefficient of 0.450 . As a result, the bank's internal social capital has indirect effects on service provision through capital activities and capital usage with a standard regression coefficient of $0.132(=0,601 \times 0,487 \times 0,450)$. Total social capital indirectly affects service provision with a standard regression coefficient of $0.355(=0.223+0.132)$. Research results from the SEM model show that internal social capital has positively contributed to the operations of Vietnam's commercial banks. Relying on internal relationship networks will help improve the working atmosphere, be willing to share and support each other's knowledge, help increase the spirit of solidarity, contribute to improving the work efficiency of the team. (Marcinkowska, 2012). The internal 
social capital of a business is the value of the personal / employee relationship in the implementation of the organization's goals and each individual contributes in increasing the opportunities to create value for the business. industry (Pietruszka-Ortyl, 2015).

\section{Recommendations}

Research results show that internal social capital of a bank affects the operations of a bank, so banks need to be fully aware of the social capital resources within the bank from which to build. analytical framework for banks to exploit this potential capital source. In its development strategies, the bank needs to define its vision, objectives and criteria to develop social capital resources within the bank.

\subsection{Building an analytical framework to access internal social capital of the bank}

In order for the quality of relationships within banks to be increased and to have effective cooperation, the maintenance and enhancement of relationships (between individuals and between functional departments) is based on always creating collaboration is very important. Therefore, it is necessary to have an analytical framework to be able to access and measure the internal social capital of the bank through specific measurement objectives and criteria including: (1) Establishing mechanisms to encourage and effectively monitor interpersonal cooperation, specifically measured by the criteria: Average number of times new knowledge is updated in the organization; level of trust and willingness to share among individuals; the average number of conflicts between individuals in the organization; the average processing time of each operation. (2) Establish a mechanism to encourage and effectively monitor cooperation among functional departments, specifically measured by the criteria including: level of trust and willingness to share across departments; the average number of conflicts between departments within the organization; average execution time of each business process.

\subsection{Creating, maintaining, developing and using the bank's internal social capital}

To maintain and develop the internal social capital of a bank, it is necessary to create and develop relationships between individuals and between functional departments both horizontally and vertically on the basis of mutual cooperation. Firstly, the bank itself has undergone a systematic process of formation and development, but it is necessary to continuously improve the system to operate effectively and to grow commitment, strictly follow the system's process on the basis of mutual cooperation. When building a management system, it is necessary to define the strength of an organization based on collective strength and close and effective cooperation between individuals and functional departments. On this basis, the bank will come up with plans to exploit and promote effectively to serve the process of building its reputation and brand. Second, banks need to focus on knowledge transfer between individuals and between functional departments to progress together and bring those knowledges to the common goals of the bank. Third, it is necessary to build a mechanism to create effective cooperation (including banking culture). Banks need to build a set of professional rules, communication processes, and customer behavior, and behavior among employees. Once a bank has built an organization's culture, all employees working within the same organization will be governed by these rules. They always work with the highest sense of responsibility to achieve the overall goals of the bank. Fourthly, building a mechanism to check and supervise effectively the cooperation between functional individuals / departments. The Bank will build internal modules (such as 5S module, mutual assessment between departments); external modules (like MS module: secret client). Specifically, the bank can hire an independent and reputable unit specializing in the task of interviewing, examining employees to assess the staff's service quality, or the bank hires collaborators to quality assessment of the bank. Building a strict and effective inspection and supervision mechanism will contribute to motivating individuals and departments to always improve the quality of customer service, thereby supporting the bank's operations to develop.

\subsection{Improve the system throughout the bank's operations}

In banking operations, systematic operations are extremely important. In reality, the cooperation between individuals / departments is still ineffective because the goals of different departments are different. For example, the corporate customer department is assigned with the target of credit, the customer must achieve sales, while the risk management department is assigned the target of reducing bad debt when making a loan decision. Thus, the risk management department must always be cautious, while the corporate customer department wants to lend immediately to meet the target. When functional departments have different goals, the cooperation is ineffective and vice versa. Therefore, banks need to have appropriate policies and objectives to reduce the conflict between functional departments. In addition, there should be standards, common frameworks for individuals and departments to adhere to those standards to perform their tasks and improve the effectiveness of cooperation between individuals and functional departments.

\section{References}

Cabrera, J. F., \& Najarian, J. C. (2015). How the built environment shapes spatial bridging ties and social capital. Environment and Behavior, 47(3), 239-267.

Chen, C. N., Tzeng, L. C., Ou, W. M., \& Chang, K. T. (2007). The relationship among social capital, entrepreneurial orientation, organizational resources and entrepreneurial performance for new ventures. Contemporary Management Research, 3(3). 
Conway, J. M., \& Huffcutt, A. I. (2003). A review and evaluation of exploratory factor analysis practices in organizational research. Organizational Research Methods, 6(2), 147-168.

Goyal, A. \& Akhilesh, K.B. (2007). Interplay among innovativeness, cognitive intelligence, emotional intelligence and social capital of work teams. Team Performance Management, 13(7/8), 206-226.

Guzzo, R. A., \& Dickson, M. W. (1996). Teams in organizations: Recent research on performance and effectiveness. Annual Review of Psychology, 47(1), 307-338.

Hair, J. F., Black, W. C., Babin, B. J., Anderson, R. E., \& Tatham, R. L. (1998). Multivariate data analysis (Vol. 5, No. 3, pp. 207-219). Upper Saddle River, NJ: Prentice hall.

Hoai, N. T., \& Dien, H. T. (2012). The Contribution of Social Capital into the Activities of Real Estate Companies in Vietnam. Journal of International Business Research, 11(3), 53.

Hulland, J., Chow, Y. H., \& Lam, S. (1996). Use of causal models in marketing research: A review. International Journal of Research in Marketing, 13(2), 181-197.

Labianca, G., \& Brass, D. J. (2006). Exploring the social ledger: Negative relationships and negative asymmetry in social networks in organizations. Academy of Management Review, 31(3), 596-614.

Marcinkowska, M. (2012). Kapitał społeczny przedsiębiorstwa-próba syntezy literatury przedmiotu. Przegląd Organizacji, 10, 20-23.

McIver, J., \& Carmines, E. G. (1981). Unidimensional scaling (No. 24). Sage.

Nisbet, P. (2007). Human capital vs social capital: Employment security and self-employment in the UK construction industry. International Journal of Social Economics, 34(8), 525-537.

Nhung, V.C., \& Phuong, L.C.M (forthcoming). External social capital banking and activities of commercial bank. Accounting.

Oh, H., Chung, M. H., \& Labianca, G. (2004). Group social capital and group effectiveness: The role of informal socializing ties. Academy of Management Journal, 47(6), 860-875.

Pastor, J. M., \& Tortosa-Ausina, E. (2008). Social capital and bank performance: An international comparison for OECD countries. The Manchester School, 76(2), 223-265.

Pietruszka-Ortyl, A. (2015) Social capital as compared to an organization's intellectual capital and intangible resources. Management of Entrepreneurship in a Knowledge Based Economy, 107-120.

Phuong, L. C. M (2020a). Corruption and long-term investment of businesses in Vietnam. Journal of Project Management, 5(4), 237-244.

Phuong, L. C. M (2020b). Corruption and stock market development in EAP countries. Investment Management \& Financial Innovations, 17(2), 266.

Phuong, L.C.M (2020c). Institutions, microeconomic factors and stock market capitalization: Evidence from the EAP countries. Accounting, 6(5), 817-824.

Ramström, J. (2008). Inter-organizational meets inter-personal: An exploratory study of social capital processes in relationships between Northern European and ethnic Chinese firms. Industrial Marketing Management, 37(5), 502-512.

Schenkel, M.T., \& Garrison, G. (2009). Exploring the roles of social capital and team-efficacy in virtual entrepreneurial team performance. Management Research News, 32(6), 525-538.

Steenkamp, J. B. E., \& Van Trijp, H. C. (1991). The use of LISREL in validating marketing constructs. International Journal of Research in marketing, 8(4), 283-299.

Thịnh, H. B. (2009). Social capital, social networks and expenses (Vốn xã hội, mạng lưới xã hội và những phí tổn). Institute of Sociology (Vietnam), 1(s 105), 42-51.

Wilson, P. N. (2000). Social capital, trust, and the agribusiness of economics. Journal of Agricultural and Resource Economics, $1-13$.

World Bank (2002). Bosnia and Herzegovina-Local Level Institutions and Social Capital. Washington D.C.

Yang, J., Brashear Alejandro, T.G., \& Boles, J.S. (2011). The role of social capital and knowledge transfer in selling center performance. Journal of Business \& Industrial Marketing, 26(3), 152-161.

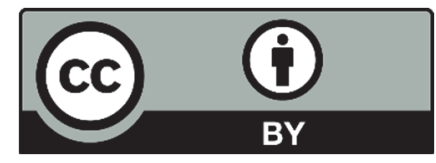

(C) 2020 by the authors; licensee Growing Science, Canada. This is an open access article distributed under the terms and conditions of the Creative Commons Attribution (CC-BY) license (http://creativecommons.org/licenses/by/4.0/). 